\title{
ARTHRODESIS OF THE SUBTALAR JOINT
}

\author{
F. Brian Thomas, Hereford, England
}

The operation to be described is a modification of the Grice $(1952,1955)$ extra-articular arthrodesis of the subtalar joint. Whereas the Grice operation sets out to correct paralytic pes valgus in children, the author's operation has been used in adults to relieve the pain of subtalar arthritis, often secondary to calcaneal fracture. The operation is technically easy to perform and seems to provide a reliable method of arthrodesing the subtalar joint. I have done twenty-three such fusions in twenty-one patients without failure.

\section{INDICATIONS FOR OPERATION}

The characteristic symptom of subtalar arthritis is pain below the lateral malleolus. If this pain is severe it is felt during normal walking. If less severe, the pain is troublesome only in walking on an irregular surface which forces the heel to invert and evert.

It has been suggested that this lateral heel pain is due to impingement of the tip of the lateral malleolus on a calcaneus that has been broadened by a crush fracture, and excision of the tip of the malleolus has been advocated (Cabot and Binney 1907, Cotton 1921, Magnuson 1923, Evans 1964). I have tried injecting lignocaine beneath the lateral malleolus but this did not have any noticeable effect on pain. On the other hand, injection of 5 millilitres of 2 per cent lignocaine into the sinus tarsi produced immediate, though of course temporary, relief of pain on walking. This is a reliable test; if relief of lateral heel pain follows the injection subtalar fusion is indicated. This is true even if, radiologically, there is evidence of midtarsal osteoarthritis.

\section{THE OPERATION}

An oblique incision two and a half inches long is made just below and in front of the lateral malleolus (Fig. 1). Fibres of the extensor digitorum brevis muscle are reflected upwards and retracted to expose the sinus tarsi. The tendon of peroneus longus is seen in the lower part of the incision. With a half-inch osteotome, a square tunnel is cut through the sinus tarsi right across to the medial side. Half of the tunnel is cut from the talus above, and the other half from the calcaneus below. The tunnel should measure about an inch from above downwards, and be as wide (from before backwards) as the thickness of the iliac crest. Part of the posterior articular facets of the subtalar joint are cut across in forming the tunnel (Fig. 2). While this is being cut, an assistant takes a graft from the crest of the ilium. The whole thickness of the crest is used and the depth of the graft must be sufficient to occupy the whole width of the sinus tarsi. The diagram (Fig. 3) shows how the graft is orientated in relation to the sinus tarsi. The inner and outer tables of the iliac graft lie at right angles to the plane of the subtalar joint, and are thus able to resist vertical compression. The unbroken cortex of the crest itself lies laterally. The graft must be a tight fit in the tunnel, so that when it has been punched home (Fig. 4) the subtalar joint should be completely locked. Any gaps behind or in front of the graft are packed with cancellous bone from the ilium.

After closure of the wound a padded below-knee plaster is applied. As there has been no disruption of the talo-calcaneal joint during the operation there is little tendency to swelling afterwards. After a week the patient is encouraged to get about with crutches, but no weight is taken on the plaster. Four weeks after operation the sutures are removed and a below-knee walking plaster is applied. Four weeks later this plaster is discarded in favour of a supporting bandage. 


\section{CLINICAL MATERIAL}

Almost half the subtalar fusions in this series followed calcaneal fractures. When the heel had taken up a valgus position after healing of the fracture this could often be correctedat least partly-at operation. If any inversion-eversion movement remained at the subtalar joint the sinus tarsi tunnel was cut with the foot held inverted. When the graft was hammered

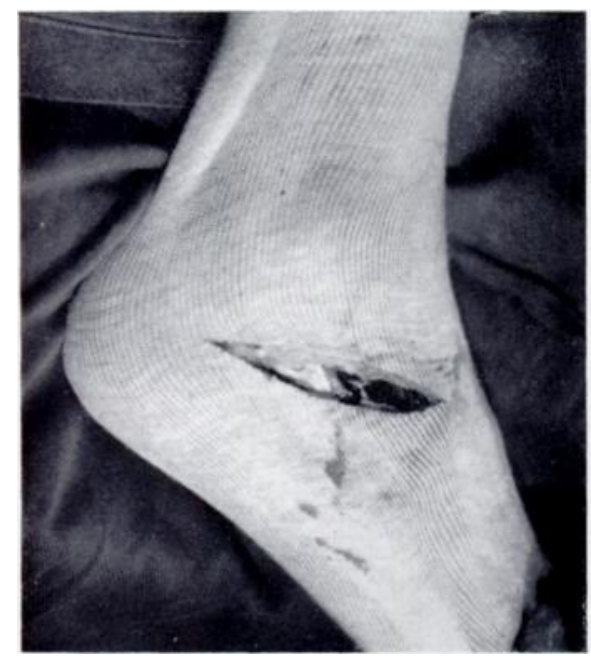

FiG. 1

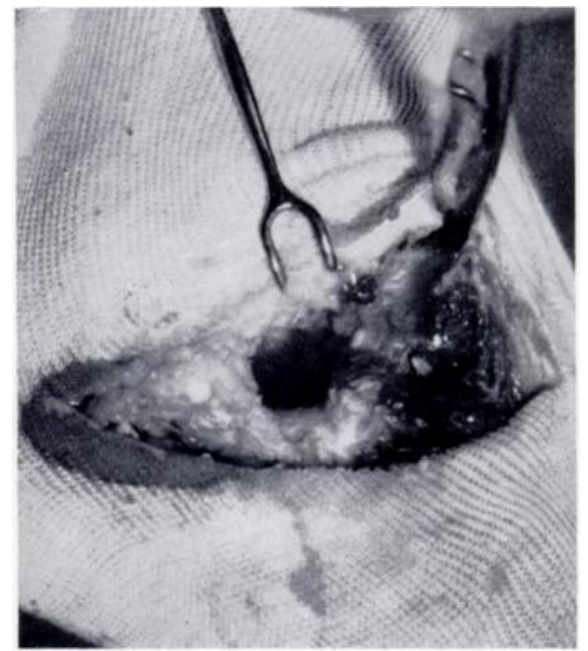

FIG. 2

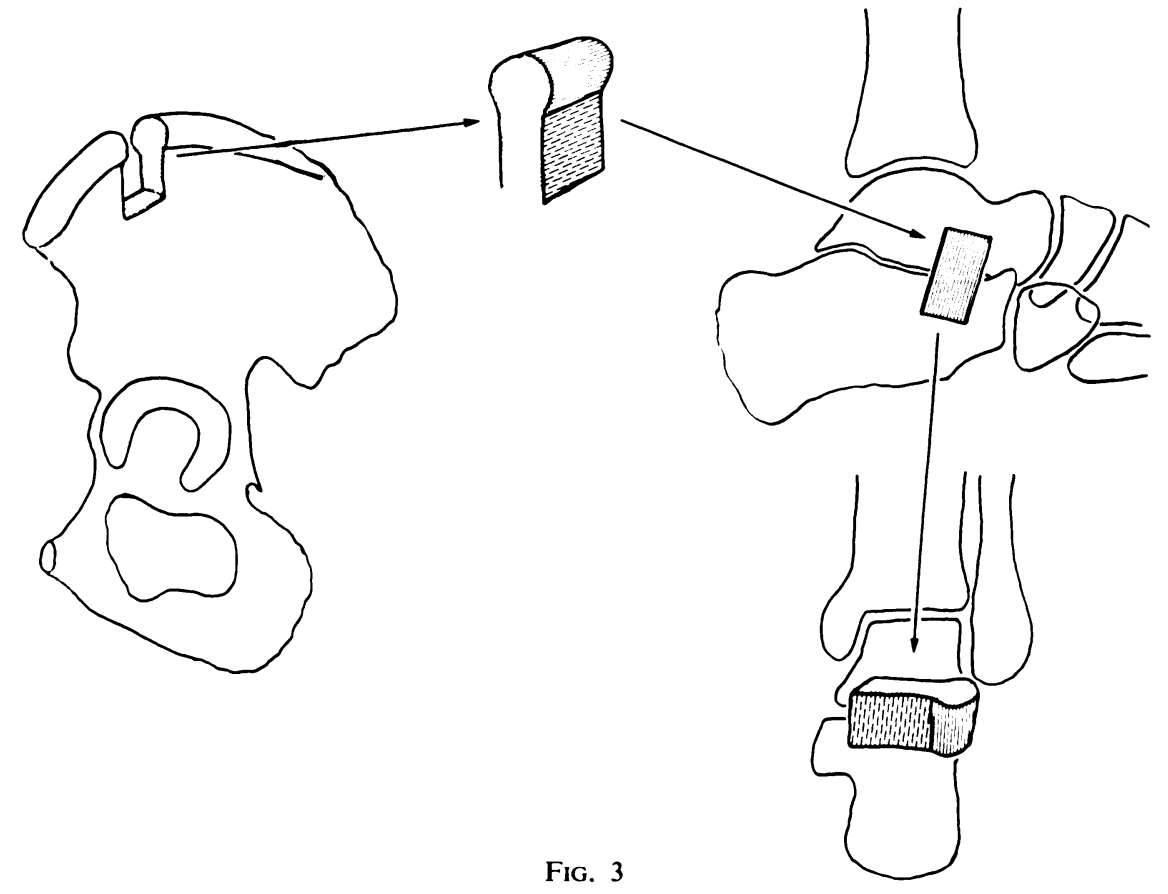

Figure 1-The incision. Figure 2-The tunnel has been cut across the sinus tarsi to receive the graft. Figure 3-Diagram to illustrate the operation.

home this position was maintained. Radiographs after operation often show that the subtalar joint surfaces have been distracted a little, particularly if the graft has fitted really tightly (Fig. 5). This is an advantage as it ensures that the graft is in compression which favours quick fusion. 
Several of the other patients in the series had radiological evidence of midtarsal osteoarthritis, but they all complained of lateral heel pain. None of them complained of pain in the midtarsal region after subtalar fusion. Overcorrection of a valgus heel into varus is not desirable. A varus heel might produce an artificially high inner longitudinal arch and this could induce midtarsal joint pain. Relevant details in twenty-three cases are given in Table I.

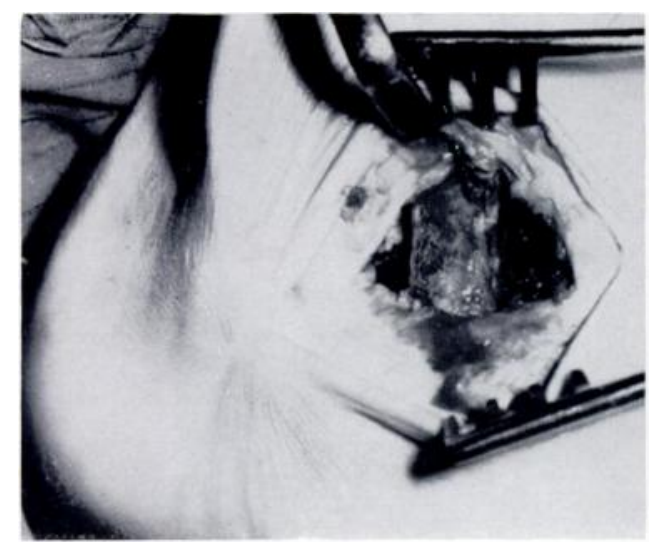

FIG. 4

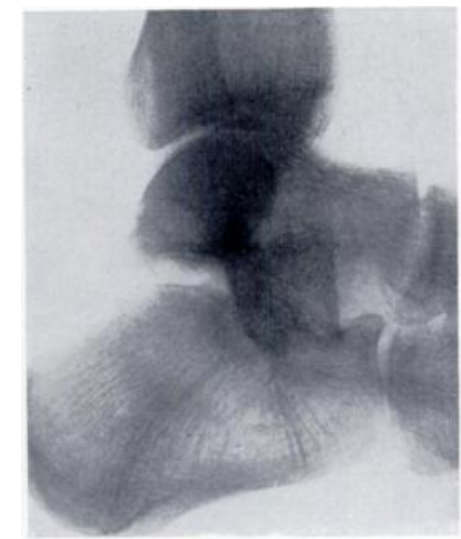

FiG. 5

Figure 4-The graft has been punched into the tunnel. Figure 5-A good tight fitting graft, with distraction of the subtalar joint surfaces.

\section{DISCUSSION}

Distortion of the subtalar joint by fracture of the calcaneus causes subtalar arthritis, and this condition provides the commonest indication for subtalar fusion in adults. The view is widely held that when the subtalar joint is to be fused the midtarsal joint must also be arthrodesed by performing a triple arthrodesis. I have found that this is an unsatisfactory procedure in middle-aged adults. The disruption of the foot at operation produces considerable oedema. In some patients this can continue indefinitely, causing stiffness of the ankle and foot, and calling for permanent wearing of an elastic stocking.

Many authors (Wilson 1927, Gallie 1943, Harris 1946, Geckeler 1950, Dick 1953, Hall and Pennal 1960) have reported satisfactory results after subtalar fusion. With minor variations most of these fusions have been carried out by Gallie's operation.

Opinions differ about the best time for fusion, when this is done for calcaneal fracture. A number of authors advocate early fusion on the assumption that the fracture will inevitably be followed by subtalar joint pain. This, however, is not the case. A number of patients resume active work after heel fractures and have little or no disability. Consequently, I assess all patients about six months after the fracture. Those patients with pain at this time are advised to undergo subtalar joint fusion. Although $I$ have not done any early fusions after calcaneal fractures there is no reason why the operation should not be used in this way. Perhaps four to six weeks after fracture would be the best time for fusion. At this time softtissue swelling should have settled and the fracture should be firm enough to be stable.

Until the present technique was evolved I used Gallie's operation for all subtalar fusions. Two failures led me to try a modification of the Grice extra-articular arthrodesis. Grice evolved his operation primarily for the treatment of paralytic pes valgus in children. His choice of twin tibial cortical grafts was presumably dictated by the fact that in children there is no appropriate donor site for a strong cancellous graft. It seemed to me that the use of tibial cortical grafts in adults had certain drawbacks. These grafts could easily knife their way into the cancellous bone of the talus and calcaneus if any movement occurred between these bones after operation. Even if the grafts succeeded in locking the subtalar joint securely, 
TABLE I

Summary of CASE ReCords

\begin{tabular}{|c|c|c|c|c|}
\hline $\begin{array}{c}\text { Case } \\
\text { number }\end{array}$ & Sex & $\begin{array}{c}\text { Age } \\
\text { (years) }\end{array}$ & Diagnosis & Clinical features \\
\hline $\begin{array}{l}1 \\
2\end{array}$ & $\begin{array}{l}\mathbf{M} \\
\mathbf{M}\end{array}$ & 32 & $\begin{array}{l}\text { Calcaneal } \\
\text { fractures }\end{array}$ & $\begin{array}{l}\text { After failed Gallie fusions both patients had more severe pain than before } \\
\text { operation. Both were asymptomatic after modified Grice fusions }\end{array}$ \\
\hline $\begin{array}{l}3 \\
4 \\
5 \\
6 \\
7 \\
8 \\
9\end{array}$ & $\begin{array}{l}\mathbf{F} \\
\mathbf{M} \\
\mathbf{M} \\
\mathbf{M} \\
\mathbf{M} \\
\mathbf{M} \\
\mathbf{M}\end{array}$ & $\begin{array}{l}57 \\
46 \\
36 \\
43 \\
40 \\
27 \\
52\end{array}$ & $\begin{array}{l}\text { Calcaneal } \\
\text { fractures }\end{array}$ & $\begin{array}{l}\text { Four patients developed fixed valgus of heels. All had severe lateral heel } \\
\text { pain approximately six months after fracture. All were relieved of pain } \\
\text { after subtalar fusion }\end{array}$ \\
\hline 10 & F & 56 & $\begin{array}{c}\text { Bilateral } \\
\text { subtalar } \\
\text { osteoarthritis }\end{array}$ & $\begin{array}{l}\text { A very heavy woman. Bilateral compound fractures tibiae and fibulae } \\
\text { 1958. Skin grafting for extensive skin loss. Persistent oedema of legs, } \\
\text { with painful valgus of feet. Lateral heel pain partially controlled for } 4 \\
\text { years wearing outside irons with inside } T \text { straps. Pain relieved after } \\
\text { bilateral subtalar fusions }\end{array}$ \\
\hline 11 & $\mathbf{M}$ & 18 & $\begin{array}{l}\text { Spasmodic } \\
\text { pes planus }\end{array}$ & $\begin{array}{l}\text { Axe wound below medial malleolus age } 13 \text {. Tibialis posterior tendon not } \\
\text { divided. Spasmodic pes planus } 2 \text { years later. No calcaneo-navicular bar. } \\
\text { Deformity corrected under anaesthesia, followed by plaster cast } 3 \text { months. } \\
\text { Outside iron with inside T strap } 3 \text { years. Still painful with marked } \\
\text { peroneo-extensor spasm. Pain-free after subtalar fusion, and full correction } \\
\text { of heel valgus was possible at operation }\end{array}$ \\
\hline 12 & $\mathbf{M}$ & 21 & $\begin{array}{l}\text { Spasmodic } \\
\text { pes planus }\end{array}$ & $\begin{array}{l}\text { Bilateral metatarsus varus age } 3 \text {. Rigid painful valgus left foot age } 15 \text {. } \\
\text { No calcaneo-navicular bar. Deformity corrected under anaesthesia } \\
\text { followed by plaster cast } 3 \text { months. Wore outside iron with inside T strap } \\
\text { for } 3 \text { years. Seen } 3 \text { years later with persistent peroneo-extensor spasm and } \\
\text { pain. Symptom-free after subtalar fusion }\end{array}$ \\
\hline 13 & F & 42 & $\begin{array}{l}\text { Bilateral } \\
\text { rigid } \\
\text { valgus feet }\end{array}$ & $\begin{array}{l}\text { Persistent lateral heel pain after inversion sprain right ankle. Bilateral } \\
\text { calcaneo-navicular synchrondroses. Left foot asymptomatic. Unrelieved } \\
\text { by wearing outside iron with inside T strap for } 6 \text { months. Pain-free after } \\
\text { right subtalar fusion }\end{array}$ \\
\hline 14 & $\mathbf{M}$ & 43 & $\begin{array}{c}\text { Subtalar } \\
\text { osteoarthritis }\end{array}$ & $\begin{array}{l}\text { Subtalar dislocation 1943. Two years history lateral heel pain. Radio- } \\
\text { graphs showed osteophytosis subtalar joint. Unrelieved by wearing } \\
\text { outside iron with inside T strap for } 6 \text { months. Pain-free after subtalar } \\
\text { fusion }\end{array}$ \\
\hline 15 & $\mathbf{M}$ & 60 & $\begin{array}{c}\text { Subtalar } \\
\text { arthritis. } \\
\text { ? rheumatoid }\end{array}$ & $\begin{array}{l}\text { Presented with peroneo-extensor spasm and lateral heel pain right foot. } \\
\text { No other joints involved. Radiographs showed rarefaction below subtalar } \\
\text { joint. Six months later osteoarthritic changes were shown. Unrelieved } \\
\text { by wearing outside iron with inside T strap for } 8 \text { months. Subtalar fusion } \\
\text { relieved his pain. Five months ago developed identical condition left foot. } \\
\text { Has just had a gastrectomy for ulcer and is postponing operation on left } \\
\text { foot }\end{array}$ \\
\hline 16 & $\mathbf{F}$ & 55 & $\begin{array}{l}\text { Painful } \\
\text { pes valgus }\end{array}$ & $\begin{array}{l}\text { Cystic degeneration left external meniscus. Following meniscectomy } \\
\text { developed painful valgus left foot. No calcaneo-navicular bar. In } \\
\text { plaster cast } 2 \text { months after correction of foot deformity under anaesthesia. } \\
\text { Wore outside iron with inside T strap for } 6 \text { months without relief of } \\
\text { lateral heel pain. Asymptomatic after subtalar fusion }\end{array}$ \\
\hline 17 & $\mathbf{F}$ & 64 & $\begin{array}{c}\text { Subtalar } \\
\text { osteoarthritis }\end{array}$ & $\begin{array}{l}\text { 1954. Painful right foot with varus heel. Radiographs showed subtalar } \\
\text { osteoarthritis. Wore inside iron with outside T strap } 6 \text { years. } \\
\text { 1956. Central dislocation arthrodesis left hip for osteoarthritis. } \\
\text { 1960. Dwyer osteotomy right calcaneum to correct varus. After this, } \\
\text { developed intractable lateral heel pain, which was relieved by subtalar } \\
\text { fusion }\end{array}$ \\
\hline 18 & $F$ & 31 & $\begin{array}{l}\text { Rheumatoid } \\
\text { polyarthritis }\end{array}$ & $\begin{array}{l}\text { Polyarthritis since age } 17 \text {. On steroids for many years. Painful valgus } \\
\text { of feet helped for a while by wearing outside irons with inside } T \text { straps. } \\
\text { Subtalar fusion on the more painful right foot, and a year later another } \\
\text { surgeon did a triple arthrodesis of the left foot. The latter still swells and } \\
\text { is uncomfortable } 10 \text { months after operation. The right foot was pain-free } \\
4 \text { months after subtalar fusion. The heel valgus was correctable at operation }\end{array}$ \\
\hline
\end{tabular}


TABLE I-continued

SUMMARY OF CASE RECORDS

\begin{tabular}{|c|c|c|c|c|}
\hline $\begin{array}{c}\text { Case } \\
\text { number }\end{array}$ & Sex & $\begin{array}{c}\text { Age } \\
\text { (years) }\end{array}$ & Diagnosis & Clinical features \\
\hline 19 & $\mathbf{M}$ & 62 & $\begin{array}{c}\text { Osteoarthritis } \\
\text { subtalar and } \\
\text { ankle joints }\end{array}$ & $\begin{array}{l}\text { Right ankle fracture age } 12 \text {. Treated by bone setter. Radiographs showed } \\
\text { osteoarthritis of ankle joint with } 25 \text { degrees inversion tilt of talus. All pain } \\
\text { felt below lateral malleolus, and this pain disappeared (temporarily) after } \\
\text { infiltration of sinus tarsi with lignocaine. Subtalar fusion abolished the } \\
\text { lateral heel pain; minimal symptoms from osteoarthritic ankle }\end{array}$ \\
\hline 20 & $F$ & 65 & $\begin{array}{l}\text { Rheumatoid } \\
\text { polyarthritis }\end{array}$ & $\begin{array}{l}\text { 1947. Arthrodesis right knee. } \\
\text { 1960. Arthrodesis left knee (at her own request). } \\
\text { 1963. Bilateral femoral fractures, following which she developed painful } \\
\text { valgus both feet. Unrelieved by wearing outside irons with inside T straps. } \\
\text { No pain in feet after bilateral subtalar fusions. Heel valgus was not } \\
\text { correctable at operation }\end{array}$ \\
\hline 21 & $\mathbf{M}$ & 61 & $\begin{array}{c}\text { Multiple } \\
\text { osteoarthritis. } \\
\text { ? gout }\end{array}$ & $\begin{array}{l}\text { Osteoarthritis both hips. Persistent lateral heel pain following inversion } \\
\text { sprain right ankle. Developed varus heel. Radiographs showed gross } \\
\text { subtalar-midtarsal osteoarthritis. E.S.R. initially } 90 \text { millimetres first hour. } \\
\text { Later fell to } 25 \text { millimetres. Serum uric acid } 6.5 \text { milligrams per cent. } \\
\text { Symptoms improved on Phenylbutazone. Biopsy from calcaneo-cuboid } \\
\text { joint showed no specific pathology. Lateral heel pain disappeared after } \\
\text { subtalar fusion, but still has minimal midtarsal pain, helped by wearing } \\
\text { valgus insole }\end{array}$ \\
\hline
\end{tabular}

their incorporation would inevitably be slow, and a long period of plaster fixation would be necessary. A massive graft cut from the ilium seemed to offer the best solution, consisting as it does of a liberal sandwich of cancellous bone between two plates of firm cortex.

\section{SUMMARY}

1. A modification of the Grice extra-articular subtalar arthrodesis is described.

2. The results of this operation are presented.

I would like to thank Mr J. B. Southern of the Robert Jones and Agnes Hunt Orthopaedic Hospital, Oswestry, for taking the photographs.

\section{REFERENCES}

Cabot, H., and Binney, H. (1907): Fractures of the Os Calcis and Astragalus. Annals of Surgery, 45, 51.

Cotron, F. J. (1921): Old Os Calcis Fractures. Annals of Surgery, 74, 294.

Dick, I. L. (1953): Primary Fusion of the Posterior Subtalar Joint in the Treatment of Fractures of the Calcaneum. Journal of Bone and Joint Surgery, 35-B, 375.

Evans, D. (1964): Personal communication.

Gallie, W. E. (1943): Subastragalar Arthrodesis in Fractures of the Os Calcis. Journal of Bone and Joint Surgery, 25, 731.

GeCKeler, E. O. (1950): Comminuted Fractures of the Os Calcis. Archives of Surgery, 61, 469.

GrICE, D. S. (1952): An Extra-articular Arthrodesis of the Subastragalar Joint for Correction of Paralytic Flat Feet in Children. Journal of Bone and Joint Surgery, 34-A, 927.

GrICE, D. S. (1955): Further Experience with Extra-articular Arthrodesis of the Subtalar Joint. Journal of Bone and Joint Surgery, 37-A, 246.

Hall, M. C., and Pennal, G. F. (1960): Primary Subtalar Arthrodesis in the Treatment of Severe Fracture of the Calcaneum. Journal of Bone and Joint Surgery, 42-B, 336.

HARrIS, R. I. (1946): Fractures of the Os Calcis. Annals of Surgery, 124, 1082.

MAGnuson, P. B. (1923): An Operation for Relief of Disability in Old Fractures of Os Calcis. Journal of the American Medical Association, 80, 1511.

Wilson, P. D. (1927): Treatment of Fractures of the Os Calcis by Arthrodesis of the Subastragalar Joint. Journal of the American Medical Association, 89, 1676.

VOL. 49 B, NO. 1, FEBRUARY 1967 